\title{
Use of Lipase Immobilized on Celluse Support for Cleaning Aged Oil Layers
}

\author{
A. M. Girelli, ${ }^{*, a}$ L. Salvagni ${ }^{b}$ and A. M. Tarola ${ }^{b}$ \\ ${ }^{a}$ Department of Chemistry and ${ }^{b}$ Department of Management, Sapienza University of Rome, \\ Piazza le Aldo Moro 5, 00185 Rome, Italy
}

\begin{abstract}
O presente estudo relata (i) a imobilização covalente da lipase de Candida rugosa sobre diferentes suportes de celulose (cotonetes, algodão para remoção de maquiagem, pó de celulose, algodão e lenços), usando periodato de sódio como agente ativo, e (ii) suas aplicações na remoção de óleo de linhaça envelhecido, de telas. A otimização das condições experimentais como pH, temperatura e tempo de reação foi realizada para o procedimento de imobilização e para a aplicação do biocatalisador. Assim, as condições ótimas de imobilização foram $\mathrm{pH} 7,0,20{ }^{\circ} \mathrm{C}, 0,3 \mathrm{mg}$ de lipase por mg do suporte e tempo de reação de $200 \mathrm{~min}$, enquanto as condições necessárias para o tratamento da superfície de telas contendo óleo de linhaça envelhecido, foram $\mathrm{pH} 6,40^{\circ} \mathrm{C}$ e tempo de reação de $45 \mathrm{~min}$. A habilidade da lipase imobilizada em remover filmes de óleo envelhecido foi confirmada por análises de espectroscopia UV-Vis, cromatografia líquida de alta eficiência (HPLC) e microscopia eletrônica de varredura (SEM).
\end{abstract}

The present study reports $(i)$ the covalent immobilization of Candida rugosa lipase on different cellulose supports (cotton buds, make-up remover pads, cellulose powder, cotton and tissues) using sodium periodate as activating agent and (ii) its application on the aged linseed oil removal from canvas. The optimization of experimental conditions such as $\mathrm{pH}$, temperature and reaction time was performed for both, immobilization procedure and the biocatalyst application. Thus

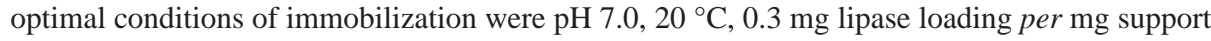
and 200 min reaction time, while those for treating canvas surface, having stratified aged linseed oil were $\mathrm{pH} 6,40{ }^{\circ} \mathrm{C}$ and $45 \mathrm{~min}$ reaction time. The ability of the immobilized lipase to remove aged oil films was confirmed by UV-Vis spectroscopy, high performance liquid chromatography (HPLC) and scanning electron microscopic (SEM) analysis.

Keywords: cleaning aged oil layers, lipase immobilized, cellulose support

\section{Introduction}

Enzymes are organic macromolecules present in all living organisms, which increase the rate of a substratum conversion. They have a high selectivity degree in the acceleration of specific chemical reactions. This happens without the formation of by-products, acting in aqueous solutions diluted in mild temperature and $\mathrm{pH}$ conditions.

Generally, hydrolases are used like amylases for polysaccharide degradation, ${ }^{1-3}$ proteases for proteic material degradation $^{1,4}$ and lipases for fat material degradation in the restoration..$^{2,4,5}$

In particular lipases are able to degrade lipids, organic molecules made of triacylglycerols.

*e-mail: annamaria.girelli@uniroma1.it
The real problem of cleaning doesn't deal with the removal of unwanted material from the surface of paintings, but by doing it without removing, disturbing or otherwise altering the original design layer. This can be extremely difficult, especially if the solubility of the overlying layer is similar to the paint binder's one. Recently, ${ }^{6-10}$ biotechnological technique is considered a useful alternative to the mechanical methods supported by solvents, spirits, alkalis, acids and soaps. Indeed it can reduce the damage to artwork since they combine an aqueous medium, which is safer than conventional highly polar organic solvents or alkaline mixtures for the user. Moreover this technique is more specific and less aggressive action because mild conditions are required. ${ }^{11-14}$ Nowadays the use of enzymes is in free solution or in gel, but this use emphasizes many drawbacks like mould, opaque, craquelure and raising, due to water penetration in painting layers for the repetitive 
washings required to remove the enzyme which generally is not completely cleared. ${ }^{1,15}$

The aim of this paper is to immobilize the lipase covalently on appropriate supporting materials, in order to overcome the above cited inconvenients of the free enzyme and to allow repetitive uses. In addition, covalent immobilization offers greatest advantages such as increasing the stability of the enzyme and preventing it from leaking into the solution. Among the numerous supports available for lipase immobilization, cellulosic materials are chosen for their availability in different economic forms, such as powder, cotton buds, make-up remover pads and tissues. In addition they can be easily activated even if they do not have reactive groups for direct coupling of enzyme. In this paper the optimum experimental conditions of immobilization ( $\mathrm{pH}$, temperature, enzyme loading, reaction time, supports) of lipase from Candida rugosa and those concerning the removal of aged stratified linseed oil on the surface of canvas (temperature, $\mathrm{pH}$, time) are presented. The study of fat compounds removed from layers treated enzymatically is made by UV-Vis spectrophotometric and HPLC analysis.

\section{Experimental}

\section{Materials}

Lipase from Candida rugosa type VII (4780 U per mg protein), glutaraldehyde $25 \%$ (v/v), tributyrrin, $\mathrm{NaH}_{2} \mathrm{PO}_{4}$, $\mathrm{Na}_{2} \mathrm{HPO}_{4}, \mathrm{NaIO}_{4}, \mathrm{CuSO}_{4}$, phenophtalein, potassium acid phthalate and all the fatty acids are purchased from Sigma-Aldrich (Milan, Italy). The solvents acetonitrile and methanol HPLC-grade, n-heptane and potassium sodium tartrate are from Carlo Erba Reagents (Milan, Italy). The standard solution of $\mathrm{KOH} 0.1 \mathrm{~mol} \mathrm{~L}^{-1}$ is from Merck, while triethylamine and $p$-bromophenacil bromide from Fluka (Milan, Italy). Linseed fresh oil is from Kremer Pigments (Aichstetten, Germany). The supports employed are: cellulose powder (Fluka Ag. Buchs, Suisse), cotton buds (Sisma s.p.a., Fortex, Europe), disc make-up remover pads (supermarket PAM s.p.a.) and cotton and linen tissues.

Purified water from Milli-Q Ultra-pure water purification system (Millipore, Bedford, Mass., USA) is used to prepare both solutions and eluents.

\section{Apparatus}

Chromatographic analyses are performed with a Kontron system (Milan, Italy), consisting of a model 422 pump and a UV-Visible 432 detector, complete with a Rheodyne 7125 injector with a $20 \mu \mathrm{L}$ sample loop
(Rheodyne, Berkeley, CA, USA). The absorbance values of the effluent monitored are registered by an integrator system constituting a PC equipped with an Intel processor, Pentium III $800 \mathrm{MHz}$ CPU, and Agilent ChemStation software for LC version A.08.03 (847) running under MS Windows NT 4.00.31 OS.

Spectrophotometric determinations are performed using a UV-Vis Uvikon 942 spectrophotometer (Kontron instruments, Milan, Italy) and cuvettes of $1 \mathrm{~cm}$ length.

Scanning electron microscope (SEM) model LEO $145 \mathrm{VP}$ is used to study the morphological properties of canvas before and after the enzymatic application.

\section{Lipase immobilization}

The lipase immobilization procedure consists of two steps: cellulose oxidation and enzyme coupling to dialdehyde cellulose (DAC) supports.

\section{Cellulose oxidation}

In order to determine the best conditions, an oxidation of cellulose $(c a .70 \mathrm{mg})$ is carried out with $5 \mathrm{~mL}$ of $0.5 \mathrm{~mol} \mathrm{~L}^{-1} \mathrm{NaIO}_{4}$ solution for 1-24 $\mathrm{h}$ at room temperature and darkness. After that, activated celluloses are filtered and washed several times with water. The formation of dialdehydic groups is confirmed by Fehling test and their amount can be determined spectrophotometrically by the absorbance decrease at $670 \mathrm{~nm}$ of the copper(II)-tartrate complex. The assay is based on the following steps: (i) reaction of activated cellulose ( $c a .70 \mathrm{mg}$ ) at $100{ }^{\circ} \mathrm{C}$ with $3 \mathrm{~mL}$ of Fehling reactive obtained by mixing equal volumes of Fehling I (69.27g hydrated copper (II) sulphate dissolved in $1 \mathrm{~L}$ of distilled water) and Fehling II (362 $\mathrm{g}$ of potassium sodium tartrate and $100 \mathrm{~g}$ of sodium hydroxide in $1 \mathrm{~L}$ ) for $10 \mathrm{~min}$; (ii) 1:8.5 dilution of $0.4 \mathrm{~mL}$ solution with deionized water; (iii) determination of \% copper(II) reacted, expressed as

$$
[\mathrm{Cu}(\mathrm{II})]_{\text {react }}=\left(\left(\mathrm{A}_{0}-\mathrm{A}\right) / \mathrm{A}_{0}\right) \times 100
$$

where $\mathrm{A}_{\mathrm{o}}$ and $\mathrm{A}$ are the absorbance at $670 \mathrm{~nm}$ of the Fehling reactive alone and with the DAC samples, respectively.

The amount of aldehydic groups in cellulose supports are finally determined by interpolation with a calibration curve obtained in the same experimental conditions (time, temperature) and employing as standard reference a dialdehyde, which reacts with Fehling test more similar to DACs. A good linear trend in the range $8-70 \%$ of $\mathrm{Cu}(\mathrm{II})$ reacted (equation $\mathrm{y}=79.124 \mathrm{x}, \mathrm{r}^{2} 0.9889$ ) is obtained plotting different glutaraldehyde amount in the range 0.05-1.2 mmol. 
Lipase coupling to dialdehyde cellulose supports

DACs are then incubated with $4 \mathrm{~mL}$ of native lipase solution $(50 \mathrm{mg}$ crude lipase in $10 \mathrm{~mL}$ phosphate buffer

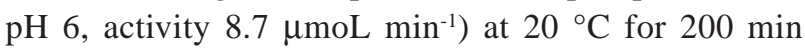
under low shaking. After binding, any unbound enzyme is removed by filtration and by washing the supports with at least $100 \mathrm{~mL}$ of water, afterwards with $100 \mathrm{~mL} 0.1 \mathrm{~mol} \mathrm{~L}^{-1}$ sodium phosphate buffer $\mathrm{pH} 6$ and stored in this buffer at $4{ }^{\circ} \mathrm{C}$ until use. The effects of time, temperature, $\mathrm{pH}$ and enzyme loading on immobilized and removed activity ratio are investigated.

\section{Lipase activity assay}

The lipase activity in the initial and filtrate solutions as well as the immobilized lipase activity is estimated employing tributyrin as substrate. The reaction mixture of free lipase activity is constituted by $0.188 \mathrm{~mL}$ of tributyrin, $1.0 \mathrm{~mL}$ of phosphate buffer and $0.25 \mathrm{~mL}$ of lipase (final volume $1.138 \mathrm{~mL}$ ), while that of immobilized lipase activity, by $2.5 \mathrm{~mL}$ of phosphate buffer, $70 \mathrm{mg}$ of biocatalyst (dry wt.) and $0.38 \mathrm{~mL}$ of substrate (final volume $2.88 \mathrm{~mL}$ ). Both the reaction mixtures are agitated and incubated for $15 \mathrm{~min}$ in the water bath at $30{ }^{\circ} \mathrm{C}$. Then the enzymatic hydrolysis is stopped by adding $10 \mathrm{~mL}$ of methanol to the total volume of the first reaction mixture and to an aliquot of $1.5 \mathrm{~mL}$ of the second one. The fatty acids formed are quantified by titration with $0.05 \mathrm{~mol} \mathrm{~L}^{-1}$ hydroxide potassium. Activities are expressed as international units (IU), where $1 \mathrm{IU}$ is defined as the amount of enzyme required to produce $1 \mu \mathrm{mol}$ of free fatty acids per minute under the assay conditions $\left(30^{\circ} \mathrm{C}, \mathrm{pH} 7\right)$ and so were determined by

free activity $(\mu \mathrm{mol}$ per min $)=\frac{\left(\mathrm{V}_{\mathrm{KOH}}-\mathrm{V}_{0}\right) \mathrm{N}_{\mathrm{KOH}} 1000}{\mathrm{t}}$

$\underset{(\mu \mathrm{mol} \text { per min per } \mathrm{g})}{\text { immobilized activity }}=\frac{\left(\mathrm{V}_{\mathrm{KOH}}-\mathrm{V}_{0}\right) \mathrm{N}_{\mathrm{KOH}} 1000 \times 1.92}{\mathrm{~g}_{\text {biocat }} \mathrm{t}}$

where $\mathrm{V}_{\mathrm{KOH}}$ and $\mathrm{V}_{\mathrm{o}}$ are, respectively, the $\mathrm{KOH}$ volume needed to titrate the samples and the respective blank, 1.92 is the factor which takes in account the aliquot $(1.5 \mathrm{~mL})$ prelevated from $2.88 \mathrm{~mL}$ of reaction mixture.

\section{Removed activity ratio}

This parameter, defined by Villanova et al. ${ }^{16}$ represented the activity removed from the enzyme solution as a consequence of the enzyme immobilization as well as the inactivation which could be produced on the non- coupled enzyme due to its interaction with the support and the coupling conditions. The removed activity ratio is calculated by:

$\mathrm{R}_{\text {rem }}^{\text {act }}(\%)=\frac{A_{1_{0}}-A_{1_{200}}}{A_{i}} \times 100$

where $\mathrm{A}_{1_{0}}$ and $\mathrm{A}_{1_{200}}$ are free lipase activity in the solution before and after the immobilization process, respectively.

\section{Activity immobilization yield}

The efficiency of immobilization is evaluated in terms of activity coupling yields. The activity coupling yield, $\eta_{\text {act }}$ $(\%)$ is calculated as follows:

$\eta_{\text {act }}(\%)=\frac{A_{2}}{A_{1}} \times 100$

where $A_{2}$ is the immobilized lipase activity and $A_{1}$ the free lipase activity.

\section{Removal of linseed oil stratified on raw canvas by biocatalyst}

An amount of fresh linseed oil is applied on small areas of raw canvas with a cotton swab and left for 2 weeks until to obtain a solid and transparent film. Successively the biocatalyst wetted in $0.1 \mathrm{~mol} \mathrm{~L}^{-1}$ phosphate buffer $\mathrm{pH} 7$, is applied to the area and pressed by a weight, so that the contact lipase-oil is well done. In order to optimise the experimental conditions the system is left undisturbed for 15-60 min range at different temperature $\left(25-50^{\circ} \mathrm{C}\right)$ in a thermostat. In the end, the lipase-cellulose support is removed and put in a glass tube in which $2.88 \mathrm{~mL}$ of extraction solvent (phosphate buffer, acetonitrile or $n$-heptane) is added. The products extraction is facilitated by sonication for $5 \mathrm{~min}$. Their identifications are made by HPLC and by UV spectroscopy (210-350 nm range, $1 \mathrm{~cm}$ cell length and the respective solvent extraction as blank). The fatty acids presence in extracts obtained by the enzymatic treatment on canvas area with linseed oil stratified respect those obtained without any enzymatic treatment an adjacent area confirmed the hydrolytic action of lipase.

\section{Chromatographic analysis}

The HPLC analyses are carried out in two different chromatographic systems so that the short and long chains fatty acids could be discriminated.

In the first system, $20 \mu \mathrm{L}$ of the extract in phosphate buffer or in acetonitrile are injected directly on a RP-18 $(25 \mathrm{~cm} \times 4.6 \mathrm{~mm}$ ID) employing a mobile phase of 
$\mathrm{H}_{2} \mathrm{O}: \mathrm{CH}_{3} \mathrm{CN}, 45: 55$ (v/v) containing $30 \mu \mathrm{L}$ of formic acid (flow rate $0.8 \mathrm{~mL} \mathrm{~min}^{-1}, \lambda=220 \mathrm{~nm}$ and room temperature).

In the second system, $20 \mu \mathrm{L}$ of phenacyl bromide esters of the fatty acids extracted in n-heptane are injected on a RP-18 (15 cm $\times 4.6 \mathrm{~mm} \mathrm{ID)} \mathrm{employing} \mathrm{a} \mathrm{mobile} \mathrm{phase}$ of $\mathrm{H}_{2} \mathrm{O}: \mathrm{CH}_{3} \mathrm{CN}, 17: 83(\mathrm{v} / \mathrm{v})$ (flow rate $1.2 \mathrm{~mL} \mathrm{~min}^{-1}$, $\lambda=242 \mathrm{~nm}$ and $45^{\circ} \mathrm{C}$ ). The derivatization process is made in accordance to literature. ${ }^{17}$ Briefly, to $250 \mu \mathrm{L}$ of lipid extract, dried under stream of $\mathrm{N}_{2}$ are added $50 \mu \mathrm{L}$ of $\alpha$-bromoacetophenone solution ( $20 \mathrm{mg} \mathrm{mL}^{-1}$ acetone) and $50 \mu \mathrm{L}$ of triethylamine ( $25 \mathrm{mg} \mathrm{mL}^{-1}$ acetone), than the solution is heated at $100{ }^{\circ} \mathrm{C}$ for $15 \mathrm{~min}$ and cooled until room temperature. Successively, $75 \mu \mathrm{L}$ of acetic acid (10 mg mL $\mathrm{m}^{-1}$ acetone) are added and reheated for an additional $5 \mathrm{~min}$ at $100{ }^{\circ} \mathrm{C}$. Finally the products are dried under stream of $\mathrm{N}_{2}$ and dissolved in mobile phase.

As control, analysis of the extracted from cellulose native and oxidized (DAC) supports (without enzyme) applied on linseed oil stratified on canvas (blanks) are also made.

\section{Results and Discussion}

\section{Oxidation degree of different cellulose supports}

The periodate oxidation of all cellulose supports, made at $20{ }^{\circ} \mathrm{C}$ and in darkness, causes the specific cleavage of the $\mathrm{C} 2-\mathrm{C} 3$ bond of glucopyranoside ring, resulting in the formation of dialdehyde cellulose (DAC).$^{18}$ This compound is spectrophotometrically determined by quantitative estimation of Fehling reaction. Figure 1 shows the spectra just of Fehling reactive (a) and after its reaction with glutaraldehyde (b) and DAC support (c). Both mixture

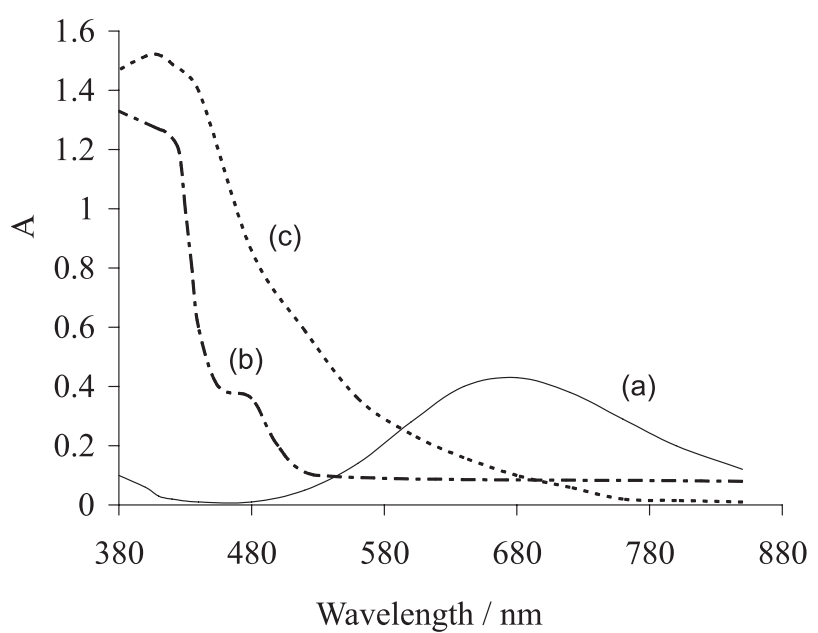

Figure 1. Spectra of Fehling reactive alone (a) and in mixture with glutaraldehyde (b) and DAC (c) after treatment at $100{ }^{\circ} \mathrm{C}$ for $10 \mathrm{~min}$. Experimental conditions: $\mathrm{b}=1 \mathrm{~cm}$, [Fehling reactive] = see Experimental section, blank $=$ deionized water reactions show a same spectral behaviour: a decrease in absorbance at $670 \mathrm{~nm}$ and a formation of maximum at $410 \mathrm{~nm}$. These confirm the presence of dialdehydic groups in activated cellulose supports.

Afterwards, the oxidation degrees of all DACs are determined after $6 \mathrm{~h}$ from the beginning of the reaction (Table 1). It shows that the number of formed aldehyde groups depends on the kind of fibres (cotton or linen) and on morphological characteristics of support materials (disc or tissue). Similar amount is shown for the cellulose powder and for the make-up remover pads. However pads disc can be used in restoration in an easier way. In fact its removal is facilitated thanks to more homogeneous and compact structures respect to powder ones. In this way the enzyme removal is easier and safer respect that of free enzyme which generally is mixed into an aqueous gel base. In addition, it can reduce the water washing and the risk of paintings damage too.

Table 1. Percentage of aldehyde groups formed in different supports by $0.5 \mathrm{~mol} \mathrm{~L}^{-1}$ periodate oxidation

\begin{tabular}{lc}
\hline Oxidized supports & \% of $\mathrm{mg}_{\text {Сно }}$ per $\mathrm{mg}_{\text {oxidized support }}$ \\
\hline Cellulose powder & 2.4 \\
Make up remover pads & 2.6 \\
Cotton tissue & 1.9 \\
Linen tissue & 1.2 \\
Cotton Bud & 0.2 \\
\hline
\end{tabular}

Optimization of lipase immobilization

The covalent immobilization of lipase to the DAC pad disc is studied estimating the effect of time, temperature, ratio lipase/support and $\mathrm{pH}$ on the immobilized and/or the residue free lipase activity. In the first case data are expressed as fatty acid produced per unit time per unit mass of support $\left(\mu \mathrm{mol} \mathrm{min} \mathrm{g}^{-1}\right)$, while in the second case they are expressed as $\mu \mathrm{mol} \mathrm{min}^{-1}$. Experiments are always made employing the same DAC disc and similar portion mass $(c a .70 \mathrm{mg}$ ) so that the same number of aldehyde groups is present.

Since immobilization time favors the enzyme-support reaction, time's course for different lipase/DAC support ratios is followed by monitoring the residue lipase activity in the solution. From results shown in Figure 2, it appears an optimal value of $200 \mathrm{~min}$, independently from the lipase/ support ratios.

Afterwards, considering the high temperature influence on the activity, the stability and the immobilization process, two series of triplicate measurements are made at 20 and $30{ }^{\circ} \mathrm{C}$. Results, obtained at $200 \mathrm{~min}$, are reported in Table 2. 


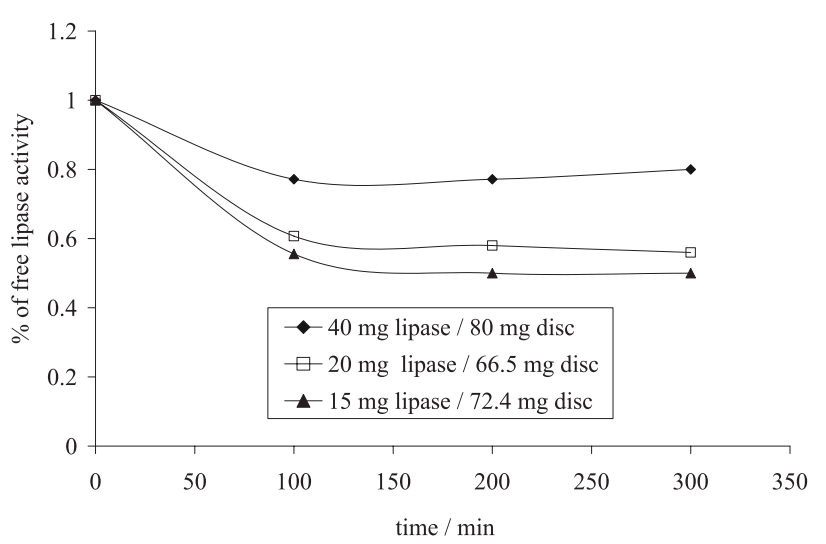

Figure 2. Influence of time on immobilization reaction of lipase from Candida rugosa on dialdehydic cellulose discs. Experimental conditions:

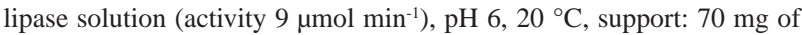
make-up removers oxidized ( $2.2 \%$ aldehyde groups).

The highest immobilized activity and immobilization yield obtained at $20{ }^{\circ} \mathrm{C}$ make this value optimal. Moreover the highest removed activity from aqueous solution, evidences a probable instability of the enzyme at $30{ }^{\circ} \mathrm{C}$ for a reaction time too prolonged.

Table 2. Effect of T on immobilization reaction. Experimental conditions: $70 \mathrm{mg}$ of make-up removers oxidized ( $2.1 \%$ of aldehyde groups),

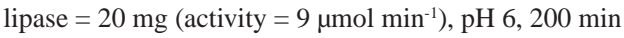

\begin{tabular}{lcc}
\hline & $20{ }^{\circ} \mathrm{C}$ & $30^{\circ} \mathrm{C}$ \\
\hline Immobilized activity / $\left(\mu \mathrm{mol} \mathrm{min}{ }^{-1} \mathrm{~g}^{-1}\right)$ & 89.9 & 53.4 \\
Removed activity / \% & 34.6 & 39.5 \\
\hline
\end{tabular}

The lipase/support ratio is also investigated to achieve binding of high levels of enzyme with a high retention of hydrolytic activity. In each experiment, $c a .70 \mathrm{mg}$ of oxidized support are immersed in a certain volume of enzyme solution. Results, reported in Figure 3, show that

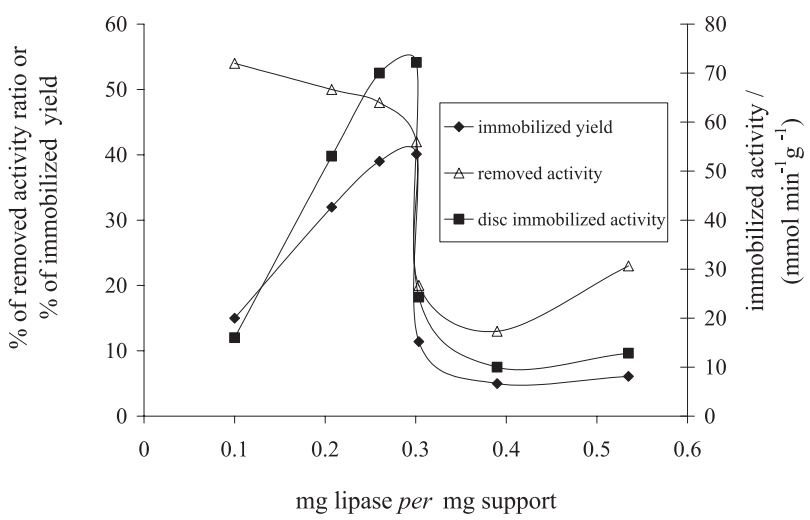

Figure 3. The influence of lipase/support $(\mathrm{m} / \mathrm{m})$ ratio on immobilization reaction of lipase from Candida rugosa on dialdehydic cellulose discs. Experimental conditions: lipase solution $\left(40 \mathrm{mg} \mathrm{mL}^{-1}\right.$, activity

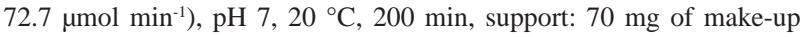
removers oxidized ( $2.2 \%$ aldehyde groups). both immobilized lipase activity and immobilization yield increase while the removed activity decreases, with the increase of the lipase/support ratio to 0.3 value. Above this value, all parameters decline roughly, evidencing the achievement of support saturation.

The effect of $\mathrm{pH}$ is also examined by the comparison of $\mathrm{pH}$-profiles in function of lipase immobilized and removed activities. Data, reported in Figure 4, show an optimal activity value at $\mathrm{pH} 7$ and a probable inactivation of the enzyme at $\mathrm{pH}>7$ for its interaction with the support as evidenced from the different behaviour of immobilized and free removed activities.

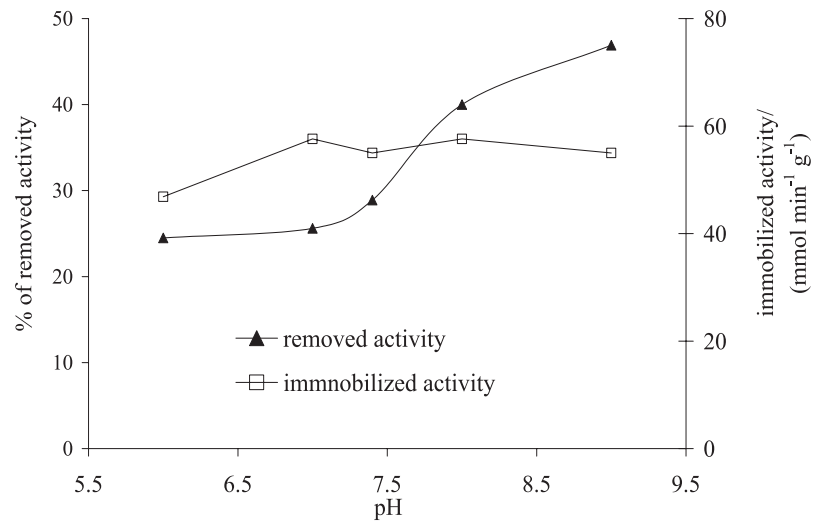

Figure 4. The influence of $\mathrm{pH}$ on immobilization reaction of lipase from Candida rugosa on dialdehydic cellulose discs. Experimental conditions: lipase solution $\left(5 \mathrm{mg} \mathrm{mL}^{-1}\right.$, activity $\left.9 \mu \mathrm{mol} \mathrm{min}^{-1}\right), 20^{\circ} \mathrm{C}, 200 \mathrm{~min}$, support: $70 \mathrm{mg}$ disc of make-up removers oxidized ( $2.1 \%$ aldehyde groups).

The immobilization stability of the lipase is investigated considering the number of possible reuse of biocatalyst and by lipase/support interactions which are correlated with $\mathrm{pH}$. These tests are carried out for 6 reuses of the biocatalysts obtained by different immobilization $\mathrm{pH}$. Figure 5 shows results, at $\mathrm{pH} 6,7,8$, and 9 , expressed as the ratio $\%$ of the immobilized activity obtained before and after reuses. It appears that, at $\mathrm{pH} 7,8$ and 9 , the biocatalyst loses just at the first reuse 60,40 and $45 \%$, respectively, while at $\mathrm{pH} 6$ a value of $57 \%$ is reached after 5 reuses. This is probably due to nucleophilic addition of amine groups of lipase to DAC aldehyde groups, which is highly influenced by $\mathrm{pH}$. This regulates aminoacid dissociation and oxygen carbonilic protonation. Therefore, at $\mathrm{pH} \mathrm{6,} \mathrm{lipase} \mathrm{is} \mathrm{more}$ highly coupled to the supports, probably, because at this value the chemical interaction is predominant with respect to the physical absorption.

\section{Enzymatic treatment}

In order to confirm the action of immobilized lipase to remove aged drying oils, a study on the compounds formed 


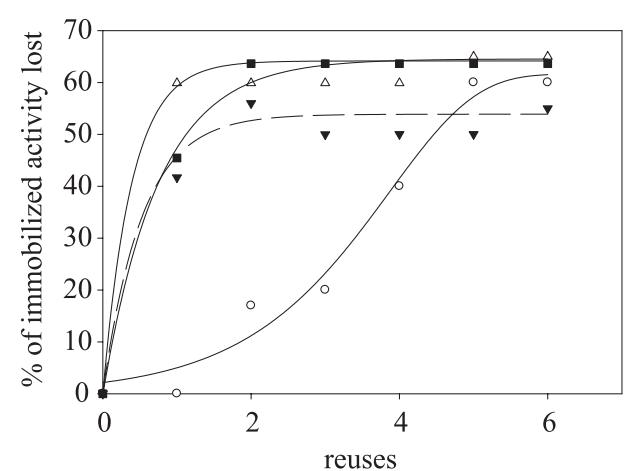

Figure 5. The effect of reuses on the \% of activity lost by lipase-make-up removers at pH $6(\boldsymbol{\nabla}), \mathrm{pH} 7(\triangle), \mathrm{pH} 8(\bigcirc)$ and $\mathrm{pH} 9(\boldsymbol{\square})$.

by the reaction between lipase and oil stratified layer is performed. The approach is based firstly on the extraction of compounds, adsorbed on the lipase-cellulose pad disc, by different solvents (phosphate buffer, acetonitrile and n-heptane) and successively on their analysis by UV-Vis spectrophotometry and HPLC. The extraction is facilitated by the use of ultrasound radiations.

The absorption spectra of extracts in phosphate buffer, acetonitrile and n-heptane, obtained after the application of the DAC support without (blank) and with immobilized enzyme (samples) on the oil stratified, show spectral behavior significantly different (Figure 6). In particular it appears a broad band around $230 \mathrm{~nm}$ in sample extracts. A shoulder at $270 \mathrm{~nm}$ is also evident in $\mathrm{n}$-heptane. These results are in accordance to the spectra of dienes $\left(\lambda_{\text {max }}=234 \mathrm{~nm}\right)$ and trienes $\left(\lambda_{\max }=270 \mathrm{~nm}\right) .{ }^{19}$ So, it is possible to hypothesize the formation of coniugated fatty acids only when the lipase-cellulose pad disc is applied on the canvas with sicative oil stratified.

The chromatographic profiles of extracts in acetonitrile and in phosphate buffer are similar. As example, only the

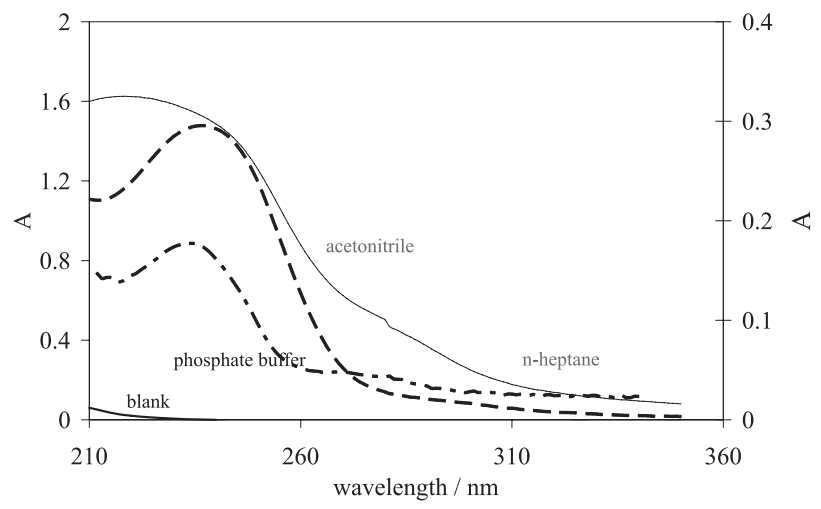

Figure 6. UV-Vis spectra of extracts from oxidized make-up remover (DAC) (blank) and from lipase-cellulose support (samples) after the disc application on the canvas, oil saturated. Experimental conditions: $\mathrm{b}=1 \mathrm{~cm}$; extraction solvents (samples) = phosphate buffer, acetonitrile and $\mathrm{n}$-heptane; extraction solvent $($ blank $)=$ acetonitrile; blanks = respective solvents. extracts of a sample in acetonitrile and of blank are reported with a standard mixture of some fatty monocarboxilic (esanoic and caprylic acids) and dicarboxilic (suberic, azelaic and sebacic acids) acids (Figure 7). So it is possible to firstly evidence the absence of fatty acids in the blank and then the presence of azelaic acid in the sample. This is consistent with the lipase oxidative process, based on hydroperoxide intermediates breaking and formation of degradation products with low molecular weight. In fact taking into account that the hydroperoxy group is generally in the middle of the $\mathrm{C} 18$ fatty acid chain, the formation of azelaic acid is highly probable. ${ }^{20}$

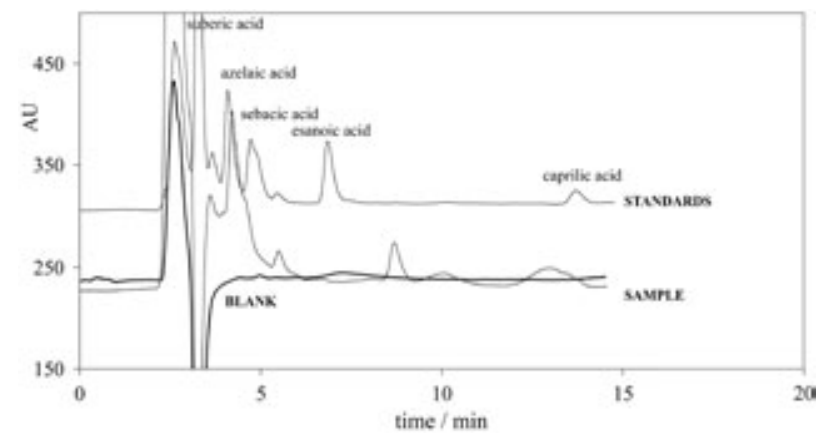

Figure 7. Chromatograms of the extracts in acetonitrile from oxidized make-up remover (DAC) (blank) and from lipase-DAC support (sample) after the cellulose disc application on the canvas, oil saturated. As reference, the chromatogram of a standard C6-C10 fatty acids mixture. Experimental conditions: column C18 $5 \mu \mathrm{m}(25 \mathrm{~cm} \times 4.6 \mathrm{~mm})$; mobile phase $\mathrm{H}_{2} \mathrm{O}: \mathrm{CH}_{3} \mathrm{CN}(45: 55$, v/v) containing $30 \mu \mathrm{L}$ formic acid; $\lambda=220 \mathrm{~nm}$; flow rate $0.8 \mathrm{~mL} \mathrm{~min}^{-1}$.

Analysis of fatty acids released by enzymatic treatment and extracted in n-heptane is carried out after their derivatization with bromophenacyl bromide. ${ }^{21}$

In Figure 8 chromatograms of extracts in n-heptane obtained by lipase-cellulose pads disc application (sample) and by DAC disc (blank) on the oiled canvas are shown. The presence of fatty acids like miristic (11.7 min), palmitic (20.4 min), oleic (21.3 $\mathrm{min})$ and

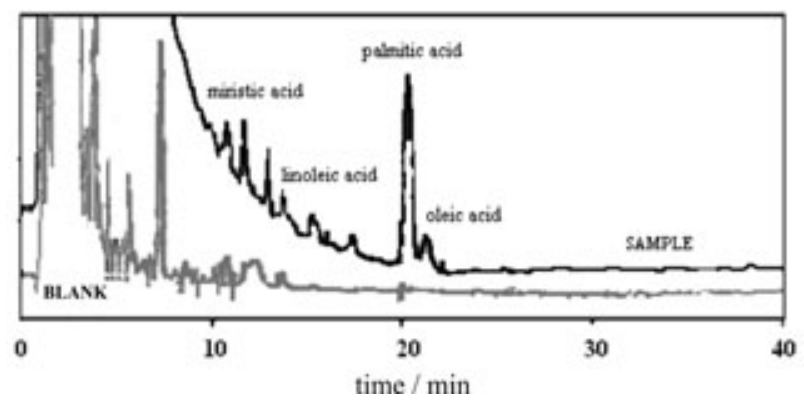

Figure 8. Chromatograms of the derivative extracts in n-heptane from oxidized make-up remover (DAC) (blank) and from lipase-DAC support (sample) after the cellulose disc application on the canvas oil saturated; experimental conditions: column C18 $3 \mu \mathrm{m}(15 \mathrm{~cm} \times 4.6 \mathrm{~mm})$, mobile phase $\mathrm{H}_{2} \mathrm{O}: \mathrm{CH}_{3} \mathrm{CN}(17: 83, \mathrm{v} / \mathrm{v}), \lambda=242 \mathrm{~nm}$, flow rate $1.2 \mathrm{~mL} \mathrm{~min}^{-1}, 45^{\circ} \mathrm{C}$. 
linoleic (13.8 min) acids is evidenced only in the sample. The absence of linolenic acid (9.6 min), probably is due to its triply unsaturation, which causes the highest reactivity in the oxidative processes.

All these features further confirm that the hydrolysis reaction of oil is activated by the lipase-cellulose treatment.

Similar conclusions are obtained by scanning electron microscope (SEM) analysis (Figure 9). In fact, it is evident by the comparison of the surfaces of the native canvas (a), with a layer of linseed oil (b) and after the lipase-cellulose
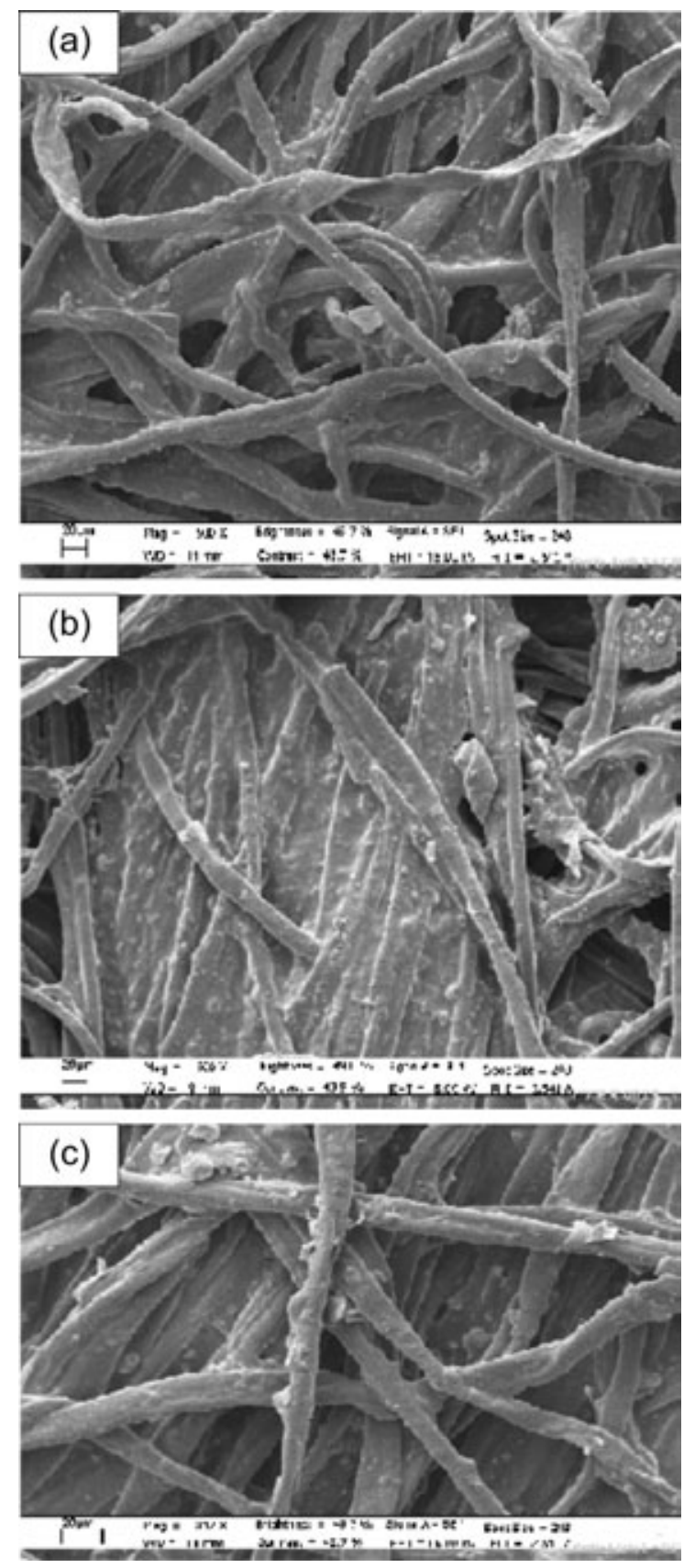

Figure 9. SEM micrographs of the canvas (a) native (magnification of $500 \times$ ), (b) with a linseed oil layer stratified (magnification of 500x) and (c) after lipase treatment (magnification of $812 \times$ ). treatment (c), that the homogenous and compact fog of the fibers present in Figure $9 \mathrm{~b}$ is reduced by the enzymatic treatment (Figure 9c).

\section{Optimization of lipase-cellulose treatment}

Temperature and application time are the experimental conditions investigated for the optimization of the lipase treatment. The effect of temperature, in the range $25-50{ }^{\circ} \mathrm{C}$, on the lipase-cellulose application is investigated by the determination of absorbance values at $235 \mathrm{~nm}$ of the extract solution. The increase of the absorbance values evidences that $\mathrm{T}$ until $40{ }^{\circ} \mathrm{C}$ favors the enzymatic reaction, and above this value a rapid decreasing is due to a probable enzyme inactivation (Figure 10).

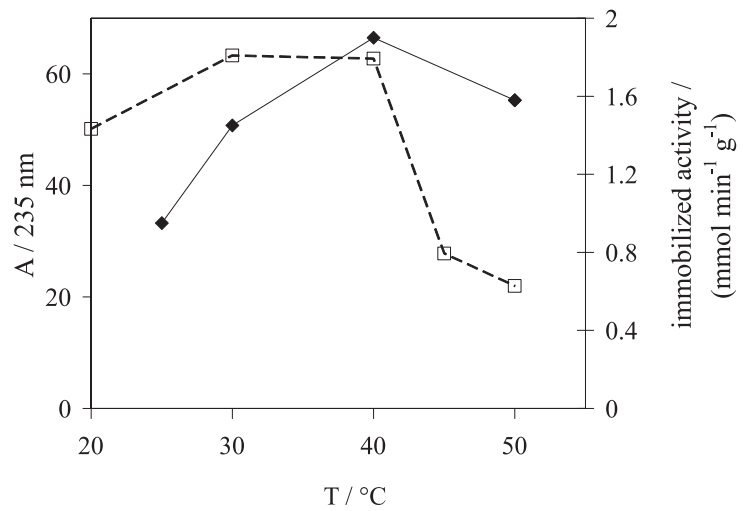

Figure 10. Temperature effect on the action of lipase-make-up removers on an aged linseed oil layer, expressed as absorbance values at $\lambda_{\max } 235 \mathrm{~nm}$. Experimental conditions: application time $45 \mathrm{~min}, \mathrm{pH}$ 7, immobilized activity $47.1 \mu \mathrm{mol} \mathrm{min} \mathrm{m}^{-1} \mathrm{~g}^{-1}$. For comparison is also reported the temperature effect on immobilized activity.

Time of the enzymatic treatment is varied between 15-60 min maintaining $\mathrm{T}$ at $40{ }^{\circ} \mathrm{C}$. Results reported in Figure 11 evidence that, above $45 \mathrm{~min}$, the reaction declines for a probable inactivation of lipase caused by a thermic

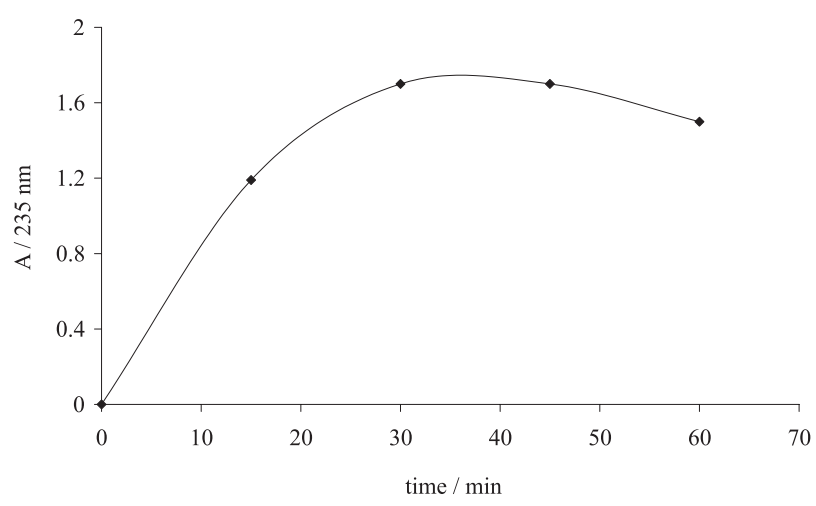

Figure 11. The effect of reaction time of lipase-make-up removers on an aged linseed oil layer, expressed as absorbance values at $\lambda_{\max } 235 \mathrm{~nm}$. Experimental conditions: $40{ }^{\circ} \mathrm{C}, \mathrm{pH} 7$, immobilized lipase activity $23.4 \mu \mathrm{mol} \min ^{-1} \mathrm{~g}^{-1}$. 


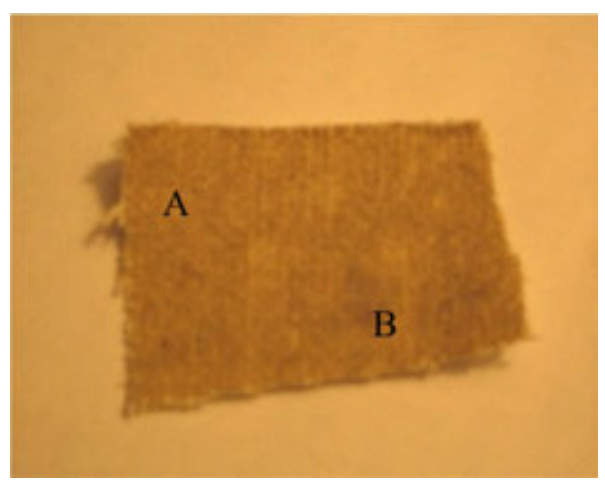

Figure 12. Photograph of canvas with an aged linseed oil layer (area A) and treated with lipase-make-up removers (quadrangular area B). Experimental conditions: $40^{\circ} \mathrm{C}, 45 \mathrm{~min}, \mathrm{pH}$ 7. Immobilized lipase activity $31.3 \mu \mathrm{mol} \mathrm{min} \mathrm{m}^{-1} \mathrm{~g}^{-1}$

treatment too prolonged. In conclusion, $40{ }^{\circ} \mathrm{C}$ and $45 \mathrm{~min}$ are chosen as the optimal values.

\section{Conclusions}

Although further research is needed to confirm these experimental findings, this newly developed method seems to be of practical importance. Indeed lipase immobilized on cellulose make-up remover supports works well to clean aged linseed oil layers, even if the reaction system is composed of solid-solid phases. This unusual approach could be a better alternative for aged siccative oil removal than the conventional one because it is safer both for the conservator's health and the integrity of the artwork. In addition, it does not require the cleaning of the painting with water since the enzyme, being chemically attached to the support, can be easily removed and even reused.

\section{Aknowledgments}

The authors are grateful to the support from University Sapienza of Rome, Italy.

\section{References}

1. Cremonesi, P.; L'uso Degli Enzimi nella Pulitura di Opere Policrome, I Talenti 4, Il Prato, $2^{\text {th }}$ ed.; Padova, 2002, $8^{\circ}$ P III-71.

2. Bellucci, R.; Cremonesi, P.; L’ Uso dei Enzimi nella Conservazione e nel Restauro dei Dipinti; Kermes, 1994, vol. VII, n. 21, p. 45.

3. Ramão, P. M. S.; Alarcão, A. M.; Viana, C. A. N.; Stud. Conservat. 1990, 35, 153
4. Beutel, S.; Klein, K.; Knobbe, G.;. Königfeld, P.; Petersen, K.; Ulber, R.; Scheper, T.; Biotechnol. Bioeng. 2002, 80, 13.

5. Borgstrom, B.; Brockman, H. L.; Lipases, Elsevier: New York, 1984.

6. Ranalli, G.; Alfano, G.; Belli, C.; Lustrato, G.; Colombini, M. P.; Bonaduce, I.; Zanardini, E.; Abbruscato, P.; Cappitelli, F.; Sorlini, C.; J. Appl. Microbiol. 2005, 98, 73.

7. Ramırez, J. L.; Santana, M. A.; Galindo-Castro, I.; Gonzalez, A.; Trends Biotechnol. 2005, 23, 584.

8. Fernandes, P.; Appl. Microbiol. Biotechnol. 2006, 73, 291.

9. Ranalli, G.; Belli, C.; Alfano, G.; Lustrato, G.; Zanardini, E.; Cappittelli, F.; Sorlini, C.; Household and Personal Care Today 2009, 3, 6 .

10. Ranalli, G.; Sorlini, C. In Plant Biology for Cultural Heritage: Biodeterioration and Conservation; Caneva, G.; Nugari, M. P.; Salvatori, O., eds.; Getty Pubblications: Hong Kong, 2009, ch. 8, p. 340.

11. Bellucci, R.; Cremonesi, P.; Pignagnoli, G.; Stud. Conservat. 1999, 44, 278.

12. Tsang, J. S.; Erhardt, D.; J. Am. Inst. Conservat. 1992, $31,87$.

13. Wolbers, R.; Aqueous Methods for Cleaning Painted Surfaces, Tawnsend, J., ed.; Archetype Publications: London, 2000.

14. Cremonesi, P.; Materiali e Metodi per la Pulitura delle Opere Policrome, $4^{\text {th }}$ ed, PHASE: Bologna, 1997, ch. 2, 3.

15. Casoli, A.; Cremonesi, P.; Rossi, P.; Preparazione e Utilizzo di Gel Enzimatici, Reagenti per la Pulitura di Opere Policrome, Progetto Restauro, Il Prato, Padova, 2000, n. 16, p. 11.

16. Villanova, E.; Manjon, A.; Iborra, J. L.; Biotechnol. Bioeng. 1984, 26, 1306.

17. Mehta, A.; Oeser, A. M.; Carlson, M. G.; J. Chromatogr., B: Anal. Technol. Biomed. Life Sci.1998, 719, 9.

18. Vicini, S.; Princi, E.; Luciano, G.; Franceschi, E.;. Pedemonte, E.; Oldak, D.; Kaczmarek, H.; Sionkowska, A.; Thermochim. Acta 2004, 418, 123.

19. Angioni, E.; Lercher, G.; Frega, N. G.; Carta, G.; Melis, M. P.; Murru, E.; Spada, S.; Banni, S.; Eur. J. Lipid Sci. Technol. 2002, 104, 59.

20. Campanella, L.; Casoli, A.; Colombini, M. P.; Marini Bettolo, R.; Matteini, M.; Migneco, L. M.; Montenero, A.; Nodari, L.; Piccioli, C.; Plossi Zappalà, M.; Portalone, G.; Russo, U.; Sammartino, M. P.; Chimica per L'arte, $1^{\text {th }}$ ed., Zanichelli: Bologna, 2007.

21. Tarola, A. M.; Girelli, A. M.; Lorusso, S.; J. Chromatogr. Sci. 2012, 50, 294.

Submitted: September 22, 2011 Published online: February 2, 2012 